\title{
Parakolonializm wietnamski jako czynnik ksztaltujący wspólczesny dyskurs o polityce i nacjonalizmie w Kambodży
}

\section{Vietnamese paracolonialism as a factor shaping the contemporary discourse on politics and nationalism in Cambodia}

\begin{abstract}
By evoking the history of bilateral Khmer-Vietnamese relations, this article depicts the perception and significance of ethnic Vietnamese people living in today's Cambodia from the viewpoint of political dispute between the two biggest local parties - The Cambodian People's Party and the Cambodia National Rescue Part, the latter of which was delegalized in November 2017. Between 1979 and 1989, Vietnam served as a protector of the People's Republic of Kampuchea and firmly controlled local socio-political relations, as well as aimed at redefining the Khmer identity in accordance with the Marxist-Leninist ideology. The legacy of that specific period, here described with the author's term 'paracolonialism', has been a crucial factor in shaping contemporary Khmer nationalism and its two opposite fractions. Both of them seek to benefit from the common enmity of Cambodian society towards Vietnamese people. The purpose of this article is to prove that the anti-Vietnamese narrative is usually deeply exaggerated, considering the actual scale of problems arising between these nations. It is also based on irrational concerns, old superstitions and stereotypes which have been deeply rooted in Cambodian society.
\end{abstract}

Keywords: Cambodia, nationalism, paracolonialism, chauvinism, Vietnam

Słowa kluczowe: Kambodża, nacjonalizm, parakolonializm, szowinizm, Wietnam

\section{Wprowadzenie}

W listopadzie 2017 r. decyzją khmerskiego Sądu Najwyższego rozwiązana została Kambodżańska Partia Ocalenia Narodowego (KPON). To jedyne ugrupowanie, które można określić mianem efektywnej opozycji wobec długoletniej hegemonii kierowanej przez premiera Hun Sena postkomunistycznej Kambodżańskiej Partii Ludowej (KPL), oskarżone zostało o planowanie 
w zmowie z agentami obcych państw kolorowej rewolucji. Jego likwidacja zapewniła KPL zdecydowaną wygraną w przeprowadzonych w czerwcu $2018 \mathrm{r}$. wyborach powszechnych i zdobycie wszystkich dostępnych miejsc w Zgromadzeniu Narodowym. Konsekwencją transformacji Kambodży w de facto jednopartyjne państwo jest m.in. duże prawdopodobieństwo ustania debaty politycznej, która od lat koncentrowała się wokół kwestii wietnamskiej, będącej często osią tarć rywalizujących stron i zarazem jedną ze spraw, które najmocniej polaryzowały społeczeństwo.

Wietnam wciąż postrzegany jest w Kambodży jako dawny ciemiężca, który w latach osiemdziesiątych XX w. wyzyskiwał Khmerów poprzez aparat biurokratyczny marionetkowej Ludowej Republiki Kampuczy (LRK) ${ }^{1}$. Oskarżenia o skrajnie zaborczy czy wręcz kolonialny charakter tej relacji wydają się nieco na wyrost, ale niewątpliwie brakuje precyzyjnego terminu definiującego zachodzącą w tym przypadku zależność. W niniejszym artykule podjęta została próba opisania przypadku z wykorzystaniem określenia parakolonializm. Podstawowym celem tego tekstu jest ukazanie dyskusji politycznej toczącej się w Kambodży od momentu przemian ustrojowych w 1993 r., z uwzględnieniem warunkującego ją czynnika wietnamskiego. Uderzająca zarówno w rząd, jak i etnicznych Wietnamczyków retoryka rasizmu i szowinizmu zderzyła się w jej ramach z narracją podkreślającą zasługi KPL w przywracaniu państwa bezpiecznego i wolnego od wojennej traumy po rządach Czerwonych Khmerów ${ }^{2}$.

Wywodzące się jeszcze z antykomunistycznej opozycji lat osiemdziesiątych przywództwo KPON od początku istnienia partii starało się kształtować wizerunek dzisiejszych elit Kambodży jako wiernych lokajów dawnego patrona, którzy po odzyskaniu przez kraj suwerenności wciąż gorliwie wypełniają polecenia płynące $\mathrm{z}$ Hanoi ${ }^{3}$. Jako naczelny argument za tą tezą przytaczano polityczny rodowód LRK, która stanowiła w pełni wietnamski konstrukt - oddany doktrynie komunistycznej i pozbawiony

1 T. Fawthrop, In Cambodia racist rhetoric brings death threats to human rights activist, „East by Southeast” [online], 22.01.2014 [dostęp: 25.03.2018], dostępny w internecie: <http://www.eastbysoutheast.com/in-cambodia-racist-rhetoric-brings-death-threats-to-human-rights-activists/>.

2 Czerwoni Khmerzy sprawujący władzę w Kambodży w latach 1975-1979 byli ekstremistycznym ugrupowaniem komunistycznym łączącym zaanektowaną na lokalne potrzeby ideologię maoistowską z khmerskim nacjonalizmem. Na czele ruchu stała niewielka grupa przywódców kierowana przez Pol Pota (właśc. Saloth Sara).

3 P. Edwards, Imaging the Other in Cambodian nationalist discourse before and during the UNTAC period, [w:] Propaganda, politics, and violence in Cambodia. Democratic transition under United Nations peace-keeping, ed. S. Heder, J. Ladgerwood, East Gate Books, New York 1996, s. 62. 
demokratycznego mandatu. W tej wizji politycznej rzeczywistości, podsycanej przez historyczne animozje wykraczające poza okres 1979-1989, Wietnam ponosi dziejową odpowiedzialność za wszelkie patologie nękające naród khmerski, a skoro członkowie dominującej KPL są z nim powiązani tożsamościowo, ideologicznie i w pewnym sensie prawnie, to należy doprowadzić do usunięcia ich ze stanowisk w ramach demokratycznych procedur. Podział na patriotów i zdrajców oraz wyzwolicieli i wichrzycieli doprowadził z czasem do wyewoluowania dwóch przeciwstawnych obozów khmerskiego nacjonalizmu. Nasilenie wzajemnych animozji wstrząsnęło sceną polityczną, a finalnym rezultatem była likwidacja KPON.

\section{Polityka parakolonialna}

Termin parakolonializm nie ma bezpośredniego umocowania w naukach o polityce i stosunkach międzynarodowych, w ramach których istnieją już dalece zaawansowane studia nad kolonializmem, a równie dużą popularnością cieszy się teoria postkolonialna, badająca mieszkańców terytoriów podległych niegdyś obcej metropolii ${ }^{4}$. Literatura przedmiotu jest przy tym bogata w prace odnoszące się do rozmaitych aspektów polityki kolonialnej, zarówno w ujęciu historycznym, jak i współczesnym. Język debaty nad problematyką kolonializmu został więc wzbogacony na przestrzeni lat o nowe pojęcia, jak protokolonializm, neokolonializm czy nawet autokolonializm ${ }^{5}$.

Pierwotne znaczenie określenia parakolonializm ukute zostało $\mathrm{w}$ ramach badań nad kulturą rdzennych społeczności narażonych na ingerencję najeźdźców, a do grona jego popularyzatorów zalicza się pisarza i etnografa Geralda Vizenora. W wydanej w 1999 r. książce pt. Manifest manners. Narratives on postindian survivance opisuje on parakolonializm na przykładzie procesu, w którym pierwotni mieszkańcy Ameryki Północnej utracili lokalną narrację historyczną na rzecz wypierającej dawne wierzenia i przekazy narracji europejskich osadników ${ }^{6}$. Parakolonializm akcentuje tym samym głównie kulturowo-ideologiczny aspekt dominacji, nie mówiąc zbyt wiele na temat sfery politycznej.

4 B. Ashcroft, G. Grittiths, H. Tiffin, Post-colonial studies. The key concept, Routledge, New York 2000, s. 168.

5 Zob. J. Seabrook, The metamorphoses of colonialism, „Globalization” 2001, vo1. 1, dostępny w internecie [dostęp: 25.03.2018]: <http:/globalization.icaap.org/content/v1.1/ jeremyseabrook.html>.

6 G. Vizenor, Manifest manners. Narratives on postindian survinance, University of Nebraska Press, Lincoln 1999, s. 69. 
Odnosząc te założenia do problematyki artykułu, należy zaznaczyć, że Wietnam formalnie nigdy nie skolonizował państwa khmerskiego wedle reguł, którymi w ekspansji terytorialnej kierowały się mocarstwa europejskie. Wkroczenie wietnamskich oddziałów do Kambodży w styczniu 1979 r. nie było przejawem imperializmu, lecz przeciwdziałaniem zagrożeniu, jakim jawił się agresywny totalitaryzm Czerwonych Khmerów. Od czasu zerwania relacji dyplomatycznych pod koniec 1977 r. rejon przygraniczny stał się areną potyczek o nieuregulowane traktatami pasy ziemi oraz scenerią masakr ludności wiejskiej, dokonywanych przez motywowanych rasistowskimi przekonaniami apologetów Pol Pota. Działacze Komunistycznej Partii Wietnamu (KPW) próbowali wypracować konsensus za pomocą kanałów dyplomatycznych, a wobec braku sygnałów zwrotnych w lutym 1978 r. podjęli decyzję o prewencyjnej inwazji na Kambodżę ${ }^{7}$. W Phnom Penh osadzony został prowietnamski rząd składający się w przeważającej części z byłych Czerwonych Khmerów, którzy zbiegli do Wietnamu w obawie przed falą czystek.

Trudno jednoznacznie uznać, że następstwa tych wydarzeń spełniają kryteria polityki kolonialnej. Popularna definicja kolonializmu zaproponowana przez Anię Loombę zakłada, że jest to działanie bazujące na inkorporacji konkretnego terytorium przy jednoczesnym zawłaszczeniu miejscowych zasobów i eksploatacji ludności, a także poddaniu kontroli okupanta rozmaitych struktur państwowych ${ }^{8}$. Inni autorzy, na przykład Ronald J. Horvath, podkreślają istotną rolę dominacji wraz $\mathrm{z}$ jej pochodnymi oraz modelowania zachowań i tradycyjnych praktyk podbitych grup 9 . Nieusuwalnym znamieniem kolonializmu jest wreszcie chęć regulowania procesów demograficznych poprzez zaplanowaną systematyczną migrację z metropolii do kolonii, a co za tym idzie przesuwanie granic rodzimej cywilizacji. Opisywany tu przypadek nie charakteryzuje się wszystkimi wymienionymi cechami, a niektóre z typowych przejawów strategii kolonialnej, np. stała obecność wojska wietnamskiego w Kambodży, wynikały raczej z obiektywnych względów bezpieczeństwa niż z celowych prób ustanowienia na jej terytorium wietnamskiej prowincji.

Mniej kłopotliwym określeniem wydaje się w tym przypadku parakolonializm, rozumiany jako praktyka uzależnienia jednego państwa od drugiego

7 P. Soja, Polityka zagraniczna Demokratycznej Kampuczy w latach 1975-1979, „Przegląd Geopolityczny" 2017, nr 20, s. 130.

8 A. Loomba, Colonialism/postcolonialism, Routledge, New York 2005, s. 11.

9 R.J. Horvath, A definition of colonialism, „Current Anthropology” 1972, vol. 13, No. 1, s. 46. 
przy jednoczesnym braku większości typowych dla machiny kolonialnej działań o znamionach eksploatacji bądź ekspansji w odniesieniu do zasobów ludzkich i materialnych. Zgodnie z pierwotnym, silnie skorelowanym $\mathrm{z}$ antropologią i etnografią, rozumieniem terminu parakolonializm odznacza się położeniem akcentu na przebudowę myślenia danego społeczeństwa na temat opresora oraz próbą redefinicji elementów jego kultury, historii i wzajemnych więzi. Opisywany poniżej model stosunków khmersko-wietnamskich nie jest zapewne jedynym przypadkiem, do którego można zastosować ten termin. W zależności od tematu parakolonializm może stanowić alternatywę dla często zbyt ostro zdefiniowanych i nieoddających w pełni złożonej sytuacji polityczno-społecznej pojęć w rodzaju kolonia, protektorat czy terytorium zależne oraz kryjących się za nimi treści.

\section{Wietnam we współczesnym dyskursie politycznym w Kambodży}

Stosunek Kambodży do Wietnamu cechuje swoisty dualizm, który objawia się odmiennością opinii i sądów w zależności od płaszczyzny interakcji. O ile khmerskie społeczeństwo przejawia wobec Wietnamczyków szereg postaw o zabarwieniu rasistowskim i szowinistycznym, o tyle oficjalne kontakty międzypaństwowe przebiegają raczej w pozytywnej atmosferze. Podobne nastroje panują w wietnamskim społeczeństwie. Na ulicach wietnamskich miast nie odnotowuje się demonstracji wymierzonych w mniejszość khmerską czy manifestacji podżegających do przemocy i nienawiści na tle rasowym czy z pobudek historycznych. Niczego niepokojącego nie ma także w wietnamskich mediach ani wypowiedziach członków KPW. Wprost przeciwnie - Wietnam uchodzi za kraj wyjątkowo dobrze odnoszący się do aspiracji khmerskiej klasy politycznej. Najlepszym dowodem jest jego długofalowe wsparcie starań Kambodży o akcesję do Stowarzyszenia Narodów Azji Południowo-Wschodniej (ASEAN) oraz jej dalszego funkcjonowania $\mathrm{w}$ ramach rodziny narodów Azji Południowo-Wschodniej po realizacji tego celu w 1999 r. $^{10}$

Obecnie Hanoi jest dla Phnom Penh kluczowym partnerem na Półwyspie Indochińskim. Zeszłoroczne obchody pięćdziesięciolecia nawiązania stosunków dyplomatycznych pomiędzy oboma państwami stały się okazją do podkreślenia wspólnych osiągnięć. Szczególnie istotny wydaje się w tym kontekście poziom gospodarek. Wietnam zajmuje dziś piąte miejsce wśród

10 A.C. Guan, Vietnam-Cambodia relations from the Paris Peace Conference (1991) to membership of ASEAN, ,South East Asia Research” 2000, vol. 8, No. 1, s. 57-58. 
największych inwestorów w Kambodży z wkładem wynoszącym ponad 3 mld dol. To ogromna zmiana w porównaniu z kwotą $800 \mathrm{mln}$ dol. ulokowanych tam w latach 1994-2011 ${ }^{11}$. W 2017 r. odnotowano największy w historii wzrost bilateralnej wymiany handlowej (ponad 30\% w ciągu dwunastu miesięcy), a do 2020 r. przewiduje się dalsze umacnianie tego trendu i kolejny skok $-\mathrm{z} 3$ do 5 mld dol. całkowitej wartości obrotów ${ }^{12}$. Ostatnie miesiące to również wzmożona współpraca obu armii ukierunkowana na organizację wspólnych ćwiczeń, dostaw broni do Kambodży, wymianę informacji wywiadowczych czy szkolenie służb granicznych ${ }^{13}$. Kryzys w obustronnych relacjach, związany z prochińskim stanowiskiem Phnom Penh w odniesieniu do napięć na Morzu Południowochińskim, wydaje się przynajmniej chwilowo zażegnany, a na szerszym forum multilateralnym ponownie rozkwita khmersko-wietnamska przyjaźń w ramach regionalnych porozumień pokroju Trójkąta Rozwoju CLV czy Wielkiego Subregionu Mekongu ${ }^{14}$.

Dokładna liczba Wietnamczyków zamieszkujących Kambodżę nie jest znana, ale większość badaczy zgadza się, że zamyka się ona w przedziale 400-700 tys. Zupełnie inne dane przedstawia Kambodżański Instytut Statystyczny, który podaje precyzyjną liczbę 14678 osób pod koniec 2013 r. ${ }^{15}$ Panująca w społeczeństwie niewiedza odnośnie do liczby Wietnamczyków zamieszkujących Kambodżę prowadziła do napięć jeszcze w czasie trwania mandatu pokojowo-administracyjnych misji ONZ w latach 1992-1993. W międzyczasie z ustaleń kończących konflikt w Kambodży porozumień paryskich z 1991 r. wycofali się Czerwoni Khmerzy, podając za jedną z przyczyn domniemaną infiltrację kraju przez wojsko wietnamskie. Dokonali przy tym szeregu masakr wśród Wietnamczyków zamieszkujących khmerskie

11 T. Leng, Small state diplomacy. Cambodia's foreign policy towards Vietnam, ,The Pacific Review" 2017, vol. 30, No. 3, s. 338.

12 V. Chheang, Cambodia-Vietnam ties turn 50, „East Asia Forum” [online], 21.06.2017 [dostęp: 25.03.2018], dostępny w internecie: <http://www.eastasiaforum.org/2017/06/21/ cambodia-vietnam-ties-turn-50/>.

13 T. Trang, Vietnam, Cambodia intensify defense cooperation, „People's Army Newspaper" [online], 18.01.2018 [dostęp: 25.03.2018], dostępny w internecie: <http:// en.qdnd.vn/military/intl-relations-and-cooperation/vietnam-cambodia-intensify-defense-cooperation-489023>.

14 Building GMS, CLV regions of sustainable, prosperous development, „Vietnam Economic News" [online], 2.04.2018 [dostęp: 2.04.2018], dostępny w internecie: <http://ven. $\mathrm{vn} /$ building-gms-clv-regions-of-sustainable-prosperous-development-31801.html>.

15 Cambodia - ethnic minorities, „Minority Rights Group International” [online], listopad 2017 [dostęp: 25.03.2018], dostępny w internecie: <http://minorityrights.org/minorities/ ethnic-vietnamese/>. 
terytorium ${ }^{16}, \mathrm{w}$ wyniku czego 21 tys. osób tej narodowości opuściło kraj $\mathrm{w}$ obawie przed eskalacją przemocy ${ }^{17}$. Wydarzenia te zostały stosunkowo słabo nagłośnione, a część formacji politycznych (głównie Buddyjska Partia Liberalno-Demokratyczna) kontynuowała ksenofobiczne ataki na społeczność wietnamską ${ }^{18}$.

Wątek wietnamski na dobre wkomponował się w mozaikę politycznego sporu w Kambodży za sprawą okoliczności wyborów powszechnych w $1998 \mathrm{r}$. Symbol khmerskiej opozycji oraz lider KPON Sam Rainsy po założeniu swojego pierwszego stronnictwa (Partia Narodu Khmerskiego, od 1998 r. Partia Sam Rainsy'ego - PSR) rozpoczął wówczas intensywną antywietnamską propagandę, dostrzegając w tym efektywny sposób na zdobycie poparcia ludu. Praktykowano wtedy głównie werbalną przemoc wymierzoną w wietnamski rząd, imigrantów, biznesmenów oraz wszelkie inne przejawy obecności niechcianego sąsiada. Za główny symbol wietnamskiego ucisku uznano sam rząd KPL, co otworzyło drogę do nazywania każdej następnej elekcji mianem bezpośredniej walki przeciwko Wietnamowi ${ }^{19}$.

Postawa Sama, byłego ministra finansów Kambodży, od zawsze budziła kontrowersje wśród zachodnich sympatyków PSR $/ \mathrm{KPON}^{20}$. Analitycy nie mieli przy tym złudzeń, że groźba nadwątlenia wizerunku progresywnego liberała była dla niego mało istotna w obliczu korzyści wynikających ze skuteczności obranej strategii mobilizacji wyborców ${ }^{21}$. Sam Rainsy odrzucał krytykę, sugerując, że nieporozumienia narosłe wokół tematu mają źródło w nieznajomości historii Kambodży, a często używane przez niego i jego zwolenników słowo youn (powszechnie uważane za obraźliwe) to tylko termin określający osobę o wietnamskich korzeniach, wcale nienacechowany pejoratywnie ${ }^{22}$. Odpierając na przestrzeni lat zarzuty o szerzenie mowy nienawiści,

16 S. Springer, Cambodia's neoliberal order. Violence, authoritarianism, and the contestation of public space, Routledge, New York 2010, s. 72.

17 Chronology of hate crimes against Vietnamese in Cambodia (part 2), „Khmer Times” [online], 15.04.2014 [dostęp: 25.03.2018], dostępny w internecie: <https://www.khmertimeskh. $\mathrm{com} /$ news/870/chronology-of-hate-crimes-against-vietnamese-in-cambodia-part-2-/>.

18 N. Chanda, Blood brothers, „Far Eastern Economic Review”, 3.12.1992.

19 C. Hughes, Khmer land, Khmer soul. Sam Rainsy, populism, and the problem of seeing Cambodia, „South East Asia Research” 2001, vol. 9, No. 1, s. 56-57.

20 Kambodżańska Partia Ocalenia Narodowego powstała w 2012 r. z połączenia Partii Sam Rainsy'ego i kierowanej przez Kema Sokhę Partii Praw Człowieka.

21 S. Strangio, Hun Sen's Cambodia, Yale University Press, New Haven 2014, s. 96.

22 S. Rainsy, Letter to the editor: 'Yuon' may be incorrect, but not offensive, ,The Cambodia Daily" [online], 10.07.2017 [dostęp: 25.03.2018], dostępny w internecie: <https://www. cambodiadaily.com/news/letter-editor-yuon-may-incorrect-not-offensive-132327/>. 
działacze PSR/KPON argumentowali, że ich komentarze są wyolbrzymiane lub przeinaczane przez zwolenników władzy, bo w rzeczywistości nawołują jedynie do respektowania praw dotyczących statusu imigranta lub procedury nabywania obywatelstwa ${ }^{23}$.

W wyborach w 2008 r. opozycja po raz pierwszy nie odnotowała wyraźnego skoku poparcia względem poprzedniej elekcji. Przyczyn takiego stanu rzeczy doszukiwano się m.in. w pomijaniu problematyki wietnamskiej podczas kampanii, co było nowością względem sytuacji z lat 1998 i 2003. Tymczasem w kraju odnotowano wzmożoną aktywność Wietnamu, na co złożyły się wzrost bezpośrednich inwestycji zagranicznych, coraz częstsze wizyty oficjeli wysokiego szczebla oraz sygnowanie w 2005 r. krytykowanego przez PSR kompleksowego porozumienia o dobrosąsiedzkich stosunkach ${ }^{24}$. Na lokalnej scenie politycznej Kambodży nastąpił natomiast rozłam w obozie współrządzących niegdyś rojalistów z FUNCINPEC, a dalsza dekompozycja partii i dryfowanie w stronę KPL sprawiły, że dla wielu głosujących jedyną realną alternatywą stał się PSR. Powrócono tym samym do dawnych metod akumulacji poparcia. Widać to było podczas wyborów w 2013 r., kiedy KPON powołała własną grupę obserwatorów, których zadaniem było niedopuszczenie do oddawania głosów przez Wietnamczyków i raportowanie o takich próbach ${ }^{25}$. Takie same działania podjęte zostały powtórnie podczas wyborów na szczeblu lokalnym w 2017 r.

Wietnamczycy stali się celem działań legislacyjnych, np. prób blokowania przez KPON możliwości nadania dużej części nielegalnie przebywającej na terytorium kraju diaspory kambodżańskiego obywatelstwa. Bezkompromisowa postawa tego ugrupowania wynikała w dużej mierze $\mathrm{z}$ sukcesywnego tracenia innych środków politycznego oddziaływania, ponieważ zaczęła z czasem realizować pod własnym sztandarem program opozycji, np. podwyżki dla pracowników sektora odzieżowego i kadry urzędniczej, obniżenie części podatków czy odkładaną dotąd reformę wymiaru sprawiedliwości. Gra wietnamską

23 Vietnamese derogatory word yuon, hate crimes and CNRP, „Khmer Times” [online], 14.04.2014 [dostęp: 25.03.2018], dostępny w internecie: <https://www.khmertimeskh.com/ news/849/vietnamese-derogatory-word------quot-yuon--quot--hate-crimes-and-cnrp/>.

24 C.A. Thayer, Cambodia and Vietnam. Good fences make good neighbours, [w:] Cambodia. Progress and change since 1991, ed. P. Sothirak, G. Wade, M. Hong, Institute of Southeast Asian Studies, Singapore 2012, s. 65.

25 M. Pann, Anti-Vietnam fears stoked ahead of Cambodia election, „VOA News” [online], 20.04.2017 [dostęp: 25.03.2018], dostępny w internecie: <https://www.voanews.com/a/ cambodian-opposition-expected-to-play-anti-vietnamese-sentiment-ahead-of-elections/ 3818107.html>. 
kartą pomagała też aktywizować Khmerów, którzy od lat mieszkali na obczyźnie, ale angażowali się w działalność antyrządową poprzez finansowe wsparcie na rzecz KPON ${ }^{26}$. Duża część z nich wyemigrowała z kraju w latach osiemdziesiątych, kiedy krytyka wpływów Hanoi jednoczyła naród wokół sprawy niepodległości i ukształtowała myślenie o polityce całego pokolenia Kambodżan.

W tyradach przeciwko Wietnamczykom KPON zwracała zwykle uwage na ich szkodliwy wpływ na lokalną gospodarkę. W 2016 r. rząd Kambodży zakazał eksportu drewna do Wietnamu, ale śledztwo Environmental Investigation Agency wykazało, że nie zaprzestano tego procederu. Wietnamska administracja zamiast walczyć z nielegalnym transportem drewna wyznaczyła kwoty ilościowe dla prowincji czerpiących zysk z handlu i opodatkowała go, przyłączając się tym samym do nielegalnej działalności. Szacowany dochód z operacji wyniósł ok. $13 \mathrm{mln}$ dol. w ciągu pół roku ${ }^{27}$. Temat ten stał się głównym wątkiem kampanii KPON przed wyborami lokalnymi w pierwszej połowie 2017 r. Jej politycy oskarżali rząd o uczestnictwo w praktykach korupcyjnych i zezwalanie na niszczenie terenów obejmujących często obszar parków narodowych. Jak pokazał raport Forest Trends, pomimo uchwalenia podobnego zakazu już w 1996 r. liczba transakcji rosła. Tylko w latach 2012-2015 kubatura sprzedawanego surowca zwiększyła się dziesięciokrotnie ${ }^{28}$.

Politycy opozycji podnosili też problem licznych wietnamskich inwestycji w Kambodży, głównie producentów kauczuku, którzy na potrzeby swojej działalności wykupywali za bezcen lub zawłaszczali rozległe połacie ziemi². Symptomem nasilenia się land grabbingu był rozrost kontrolowanych przez wietnamskich monopolistów plantacji, które w 2013 r. zajmowały aż 300 tys. hektarów $^{30}$. Z drugiej strony działalność Wietnamczyków i wytwarzanie lateksu przynosi lokalnej ludności wymierne korzyści: tysiące nowych miejsc

26 P. Millar, Race to the bottom. How Cambodia's opposition is targeting ethnic Vietnamese, „Southeast Asia Globe” [online], 21.10.2016 [dostęp: 25.03.2018], dostępny w internecie: $<$ http://sea-globe.com/cambodia-opposition-cnrp-vietnamese/>.

27 L. Hunt, Why is Cambodia's illegal logging problem still rolling on?, „The Diplomat” [online], 10.05.2017 [dostęp: 25.03.2018], dostępny w internecie: <https://thediplomat. com/2017/05/why-is-cambodias-illegal-logging-problem-still-rolling-on/>.

28 Vietnam's imports of Cambodian logs and sawnwood from natural forests: 2013-2015, „Forest Trends Report Series”, listopad 2016, s. 3, dostępny w internecie [dostęp: 20.07. 2018]: <https://www.forest-trends.org/wp-content/uploads/imported/vietnam-cambodia-report-formatted_final_11-23-16-pdf.pdf $>$.

29 T. Leng, Small state diplomacy..., s. 338.

30 J. Head, Vietnam firms involved in 'illegal land grabs', „BBC” [online], 13.05.2013 [dostęp: 25.03.2018], dostępny w internecie: <http://www.bbc.com/news/world-asia$-22509425>$. 
pracy, wpływy z podatków czy pieniądze za udostępnienie ziemi pod uprawy. W maju 2016 r. deputowani KPON wysłali do premiera list, w którym domagali się respektowania ustawowego zakazu dzierżawy gruntów wietnamskim kontrahentom, nagminnie łamanego przez administrację terenową. Rząd zdecydował, że z powodu niedostatecznych informacji o skali zjawiska oraz zatajaniu dzierżawy przez chłopów pozwoli na realizację zawartych dotąd kontraktów ${ }^{31}$.

Innym frontem walki politycznej są nieuregulowane od dziesięcioleci spory graniczne Wietnamu i Kambodży, które jeszcze w latach dziewięćdziesiątych rodziły sporadyczne starcia pomiędzy armiami obu państw ${ }^{32}$. W $2015 \mathrm{r}$. KPON rozpoczął kampanię mającą uświadomić społeczeństwu, że przy demarkacji khmersko-wietnamskiej linii granicznej rząd posługiwał się spreparowanymi mapami. Miały się one różnić od tych, które w 1964 r. przekazane zostały Organizacji Narodów Zjednoczonych przez Norodoma Sihanouka i odpowiadały faktycznemu przebiegowi granicy. Zarzuty o zdradę stanu upadły po interwencji Hun Sena - udowodnił on, że dokumenty będące w posiadaniu ONZ są zgodne z tymi, które posłużyły za bazę nowych regulacji terytorialnych w $2005 \mathrm{r}^{33}$ Konsekwencją tych wydarzeń było aresztowanie jednego z czołowych deputowanych KPON oraz jej senatora pod zarzutem dezinformowania opinii publicznej ${ }^{34}$. Podobne orzeczenie wydano w sprawie Sam Rainsy'ego, zaangażowanego w niszczenie słupków granicznych podczas jednej z wizyt na wschodzie kraju. W 2017 r. polityk usłyszał wyrok pięciu lat pozbawienia wolności ${ }^{35}$.

Widząc coraz lepsze wyniki wyborcze $\mathrm{KPON}^{36}$, strona rządowa sporadycznie próbowała uderzać w podobne tony, by zbić kapitał polityczny. Były

31 T. Vida, CNRP: Vietnamese renting land, „Khmer Times” [online], 26.10.2016 [dostęp: 25.03.2018], dostępny w internecie: <https://www.khmertimeskh.com/news/28992/cnrp-vietnamese-renting-land>.

32 R. Amer, Border Conflicts between Cambodia nad Vietnam, „IBRU Boundary and Security Bulletin" 1997, Summer, s. 83.

33 T. Leng, 2016: a promising year for Cambodia?, „Southeast Asian Affairs” 2017, vol. 1, s. 141.

34 M. Dara, B. Sokhean, Hun Sen tells jailed opposition figures not to expect pardon, „The Nation" [online], 7.03.2018 [dostęp: 25.03.2018], dostępny w internecie: <http://www. nationmultimedia.com/detail/asean-plus/30340397>.

35 K. Sovuthy, CNRP president Sam Rainsy sentenced to a further five years in prison, „The Cambodia Daily” [online], 27.12.2016 [dostęp: 25.03.2018], dostępny w internecie: $<$ https://www.cambodiadaily.com/news/cnrp-president-sam-rainsy-sentenced-five-years-prison-122517/>.

36 KPON uzyskała w wyborach parlamentarnych w 2013 r. ponad 44\% głosów. Dla porównania wynik Partii Sam Rainsy’ego w latach 2003 i 2008 dwukrotnie wyniósł 21,9\%. 
to działania doraźne, lecz spektakularne, polegające zwykle na przesiedlaniu wietnamskiej ludności. Masowe eksmisje objęły przede wszystkim mieszkańców tzw. pływających wiosek w prowincjach Siěm Réab, Kândal, Krâchéh czy Kâmpóng Chhnăng. Czasami motywowano je rozwojem przemysłowym okolicy, jednak najczęściej powoływano się na aspekty środowiskowe i ekologiczne, co wydaje się nie mieć umocowania w rzeczywistości ${ }^{37}$, ponieważ wysiedlenia nie dotknęły żyjącej na tych terenach ludności khmerskiej ani mniejszości czamskiej.

Siły rządowe próbowały też skompromitować opozycję, stosując przy tym jej własną broń. W 2013 r. upubliczniono nagranie audio, w którym Kem Sokha neguje fakt masowych morderstw w katowni Tuol Sleng, gdzie Czerwoni Khmerzy torturowali i zabili około 12 tys. osób oskarżonych o spiskowanie przeciwko reżimowi. Miał on stwierdzić, że więzienie to jest mistyfikacją wymyśloną przez wietnamskiego okupanta po wkroczeniu do Kambodży. Jego argumentacja przypominała wywód, który w swoim ostatnim wywiadzie wygłosił Pol $\mathrm{Pot}^{38}$. Kem Sokha potwierdził autentyczność nagrań, ale zastrzegł, że taśma została zmanipulowana poprzez pocięcie wypowiedzi i zmontowanie jej w innej kolejności. Nie rozstrzygając tej konkretnej sprawy, należy stwierdzić, że nie byłby to odosobniony przypadek osobliwej interpretacji historii przez członka KPON. Sam Rainsy na kartach wydanej w tym samym roku autobiografii zaznaczył bowiem, że zbrodnie popełnione przez khmerskich komunistów nie usprawiedliwiały wietnamskiej okupacji ${ }^{39}$. Tego rodzaju uwagi prowadzą do konkluzji, że nie ma większej różnicy między losem Khmerów w Demokratycznej Kampuczy a kambodżańską rzeczywistością lat osiemdziesiątych. Ciężko też trafić w książce na ślady głębszej refleksji nad poparciem, jakiego polityk ten udzielał wówczas Koalicyjnemu Rządowi Demokratycznej Kampuczy (KRDK), w którym jedną z trzech frakcji stanowili Czerwoni Khmerzy.

W ostatnich miesiącach istnienia KPON kwestia wietnamska była przedmiotem sporu między jej przywódcami, w związku z czym pojawiały się

37 T. Frewer, Cambodia's anti-Vietnam obsession, „The Diplomat” [online], 6.09.2016 [dostęp: 25.03.2018], dostępny w internecie: <https://thediplomat.com/2016/09/cambodias-anti-vietnam-obsession/>.

38 C. Osterheld, Scapegoating Cambodia's "yuon". Historical perspectives on Khmer anty-Vietnamism, [w:] Proceedings of the $10^{\text {th }}$ International Academic Conference, Vienna, Austria, 03-06 June 2014, ed. J. Rotschedl, K. Čermáková, Prague 2014, s. 582.

39 D. Hutt, The truth about anti-Vietnam sentiment in Cambodia, „The Diplomat” [online], 20.10.2016 [dostęp: 25.03.2018], dostępny w internecie: <https://thediplomat. com/2016/10/the-truth-about-anti-vietnam-sentiment-in-cambodia/>. 
sprzeczne sygnały odnośnie do kształtowania polityki partyjnej wobec tego zagadnienia. W wywiadzie dla dziennika „The Phnom Penh Post” Kem Sokha zapewniał, że ponieważ partia przygotowuje się do przejęcia władzy w $2018 \mathrm{r}$. i musi zająć się sprawami bliskimi społeczeństwu, to nie ma już potrzeby podtrzymywania antywietnamskiej retoryki. Wypowiedź ta sugeruje, że zawiłości dwustronnych relacji z Wietnamem nie są główną troską Khmerów, a podnoszenie ich $w$ debacie służyło wyłącznie celom instrumentalnym. Anonimowo zbliżone opinie wyrażano zresztą już znacznie wcześniej ${ }^{40}$. Przewodniczący KPON przyznał, że należy powstrzymać dalsze protesty, a wątpliwości natury formalnoprawnej rozwiązywać poprzez działania dyplomatyczne w zgodzie $\mathrm{z}$ prawem międzynarodowym ${ }^{41}$. Zaledwie tydzień po wyemitowaniu wywiadu dwaj inni członkowie formacji, w tym wpływowy książę Sisowath Thomico, przemawiając z okazji rocznicy przekazania dawnych kambodżańskich ziem w Delcie Mekongu pod wietnamską kuratelę, podkreślili potrzebę odzyskania ziem w delcie Mekongu i uruchomienia międzynarodowej kampanii poparcia tego celu po ewentualnym zwycięstwie w wyborach parlamentarnych ${ }^{42}$.

Żądania przegnania Wietnamczyków oraz wyzwolenia kraju z rąk komunistycznej agentury występowały też często w propagandzie liderów Ligi na Rzecz Demokracji czy Partii Khmerskiej Siły ${ }^{43}$. W dyskurs ten zaangażowały się ponadto środowiska akademickie, czego wyrazem była wiodąca rola Kambodżańskiej Federacji Studentów i Intelektualistów w protestach pod ambasadą Wietnamu w Phnom Penh w 2014 r. ${ }^{44}$ Nawet znany obrońca demokracji Kem Ley nie szczędził za życia słów pogardy pod adresem Hanoi, tworząc m.in. sugestywną teorię o pięciu stadiach destrukcji Kambodży przez Wietnam i propagując ją podczas tzw. kampanii $100 \mathrm{dni}^{45}$. Głosy sprzeciwu wobec podobnych postaw, padające ze strony takich osób jak politolodzy Muoy Piseth czy Sophal Ear, to rzadkość. Próba prezentacji wyważonych poglądów wywołuje

40 Tenże, Sam Rainsy. A coward?, ,The Diplomat” [online], 23.06.2016 [dostęp: 25.03.2018], dostępny w internecie: $<$ https://thediplomat.com/2016/06/sam-rainsy-the-coward/>.

41 Opposition leader Kem Sokha talks politcs, power and Hun Sen, „You Tube” [online], 20.06.20147 [dostęp: 25.03.2018], dostępny w internecie: <https://www.youtube.com/ watch?time_continue $=201 \& \mathrm{v}=$ Slu3Y0P-K_8>.

42 A. Willemys, CNRP clings to anti-Vietnamese rhetoric, „The Phnom Penh Post” [online], 26.06.2017 [dostęp: 25.03.2018], dostępny w internecie: <https://www.phnompenhpost. com/national/cnrp-clings-anti-vietnamese-rhetoric>.

43 T. Frewer, Cambodia 's...

44 M. Kunthear, Clash at Vietnam embassy, „The Phnom Penh Post” [online], 9.06 .2014 [dostęp: 25.03.2018], dostępny w internecie: <https://www.phnompenhpost.com/national/ clash-vietnam-embassy>.

45 T. Frewer, Cambodia 's... 
gniew opinii publicznej, o czym przekonał się Ou Virak, szef Kambodżańskiego Centrum Praw Człowieka, któremu za publikację komentarzy potępiających mowę nienawiści grożono na jednym z portali społecznościowych śmiercią ${ }^{46}$.

Rzeczywista sytuacja Wietnamczyków w Kambodży jest jednak zupełnie inna niż obraz, jaki próbowała stworzyć przed narodem opozycja. W świetle wyników badań terenowych nad statusem grup etnicznych zamieszkujących ten kraj widać, że diaspora podlega wielu restrykcjom ze strony państwa. Co prawda dyskryminacja motywowana jest czysto politycznie i nie napędza jej tradycyjnie rozumiany rasizm, ale skutki są podobne. Wietnamczycy z reguły pozbawieni są kambodżańskiego obywatelstwa, nie mogą brać udziału w wyborach ani legalnie pracować. Problemy z uzyskaniem zgody na zawarcie małżeństwa, podróżowaniem po kraju, zdobyciem prawa jazdy czy kupnem zwykłej karty SIM to nadal część ich codziennego życia ${ }^{47}$. Ludzie ci tworzą zamknięte wspólnoty, gdzie integracja najczęściej nie wykracza poza krąg najbliższych krewnych i znajomych, co w połączeniu z niechęcią do nauki języka skutecznie alienuje ich od otoczenia ${ }^{48}$. Brak politycznej reprezentacji oraz fakt, że mniejszość wietnamska nie liczy się jako potencjalny elektorat, prowadzi do wyłączenia jej z dyskursu politycznego i braku zainteresowania jej problemami ze strony lokalnych polityków ${ }^{49}$.

Okolicznościom tym towarzyszy bierność Wietnamczyków w kontestacji zastanego porządku. Kluczowym czynnikiem inercji tej mniejszości pozostaje strach przed ewentualnymi represjami ze strony Kambodżan, dla których aktualny stan jest zupełnie zrozumiały, a bywa nawet interpretowany jako rekompensata za historyczne krzywdy. Ignorowana społeczność nie jest więc w stanie powołać znaczącej organizacji na rzecz równouprawnienia - odpowiednika ruchów walczących o prawa człowieka i reprezentujących sprawę mniejszości khmerskiej w Delcie Mekongu, których głos coraz donioślej dociera do społeczności międzynarodowej ${ }^{50}$. Właśnie takie sygnały niejednokrotnie służyły politykom KPON do budowania narracji, że życie khmerskiej

46 M. Kimseng, Not only Vietnamese threatened by racism, human rights worker says, „VOA Cambodia” [online], 25.02.2014 [dostęp: 25.03.2018], dostępny w internecie: $<$ https://www.voacambodia.com/a/not-only-vietnamese-threatened-by-racism-rightsworker-says/1858791.html>.

47 S. Ehrentraut, Challenging Khmer citizenship. Minorities, the state, and the international community in Cambodia, rozprawa doktorska, Uniwersytet Poczdamski, 2013, s. 71.

48 Tamże, s. 79.

49 Tamże, s. 84.

50 Zob. Khmer Krom. Khmer Kampuchea-Krom Federation (KKF). Member Profile, Unrepresented Nations and Peoples Organization, Washington 2018, dostępny także w internecie [dostęp: 25.03.2018]: <https://unpo.org/members/7887>. 
mniejszości w Wietnamie przypomina piekło, podczas gdy Wietnamczycy cieszą się w Kambodży wolnością i szczęściem ${ }^{51}$.

W przeprowadzonej w 2003 r. przez The Asia Foundation ankiecie, która badała nastroje khmerskiego elektoratu, aż $37 \%$ respondentów stwierdziło, że Wietnam wciąż stara się eksploatować Kambodżę i dominować nad nią ${ }^{52}$. Niewykluczone, że przygotowany przez prestiżowy ośrodek analityczny raport stanowił punkt odniesienia dla programowania agendy politycznej KPON w kolejnych latach. W 2014 r. druga edycja sondy zawierała pytanie o dostrzeżone nieprawidłowości podczas przeprowadzonej rok wcześniej elekcji. Aż 13\% osób udzieliło zadziwiającej odpowiedzi o nieuprawnionym udziale w głosowaniu obywateli wietnamskich. Był to trzeci z najczęściej wskazywanych punktów - po usuwaniu z list nazwisk konkretnych kandydatów oraz szerzej niezdefiniowanych oszustwach przy urnie wyborczej ${ }^{53}$. Ten osobliwy zarzut, którego autentyczności nie potwierdziła dokumentacja międzynarodowych obserwatorów, przywołuje na myśl komentarze członków KPON, że przytoczony proceder jest tradycyjnym zjawiskiem we wschodnich prowincjach, gdzie KPL otwarcie korzysta z pomocy głosujących zamiast Khmerów Wietnamczyków ${ }^{54}$.

Niechęć do mniejszości wietnamskiej dobrze obrazują też badania International Republic Institute z 2014 r., w których podobna grupa respondentów (15\%) wymieniła nielegalną wietnamską migrację w pytaniu o kluczowe wyzwania, przed którymi stoi Kambodża ${ }^{55}$. Dopełnienie tych statystyk stanowi rekordowe 38,9\% odpowiedzi wskazujących w osobnym badaniu The Asian Foundation, że błędna polityka rządu w stosunkach z Wietnamem to największa bolączka w relacjach międzynarodowych państwa ${ }^{56}$.

51 S. Ehrentraut, Challenging Khmer citizenship..., s. 89.

52 Democracy in Cambodia - 2003. A survey of the Cambodian electorate, ed. T. Meisburger, The Asia Foundation 2003, s. 77, dostępny w internecie [dostęp: 16.02.2018]: $<$ https://asiafoundation.org/resources/pdfs/DemocracyinCambodia.pdf $>$.

53 Democracy in Cambodia - 2014. A survey of the Cambodian electorate, The Asia Foundation 2014, s. 45, dostępny w internecie [dostęp: 16.02.2017]: <https:/asiafoundation. org/resources/pdfs/DemocracyinCambodia2014.pdf $>$.

54 S. Springer, Cambodia 's..., s. 99.

55 Survey of Cambodian public opinion, International Republican Institute 2013, s. 8, dostępny w internecie [dostęp: 16.02.2017]: <http://www.iri.org/sites/default/files/Cambodian\%20Poll\%209\%20Final\%20PUBLIC.pdf>.

56 M. Babović, D. Vuković, Cambodia. A survey of livelihood strategies and expectations for the future, The Asia Foundation 2015, s. 36, dostępny w internecie [dostęp: 16.02.2018]: <https://asiafoundation.org/resources/pdfs/CambodiaLivelihoodsandFutureExpecationsSurvey.pdf $>$. 


\section{Dwa oblicza khmerskiego nacjonalizmu}

Khmerski nacjonalizm jest wypadkową kilku czynników, które kumulując się, wyznaczały jego rys i zarazem bardzo precyzyjne granice. Najistotniejsze znaczenie dla zrozumienia tego zjawiska mają przesłanki historyczne.

Na przestrzeni wieków w świadomości Kambodżan wyewoluował hermetyczny w treści pogląd, który pozwala obecnie wyrokować wedle ostrych i uproszczonych kryteriów, kto może być uznany za równorzędnego członka społeczności, a komu należy przypiąć etykietkę wroga narodu. Jak słusznie zauważa Penny Edwards, Khmerzy od wieków zwykli postrzegać siebie jako jednostki stanowiące kwintesencję dobrych cech charakteru i zachowań. Jawili się sobie skromni, delikatni, uprzejmi i szczodrzy, a więc i potrzebujący solidnego patrona $\mathrm{w}$ starciu z prezentującymi zgoła odmienne wartości Wietnamczykami ${ }^{57}$. Zadecydowało to o zwróceniu się w 1863 r. do Francji z propozycją roztoczenia nad państwem opieki. Identyczne motywacje w połączeniu z instytucjonalną słabością państwa po upadku Imperium Angkoru skłaniały Kambodżę do podobnych posunięć, kiedy w zależności od aktualnej sytuacji ich obrońcami bywali Tajowie czy właśnie Wietnamczycy. Symptomatyczne, że po czasie dawni sprzymierzeńcy zawsze okazywali się zdrajcami żądnymi zawłaszczenia khmerskiej ziemi, siły roboczej czy zdobyczy kultury, a przekształceni w uzurpatorów wymagali znalezienia przeciw nim nowego sojusznika. Powtarzało się to periodycznie, a wśród kolejnych przeciwników, w zależności od momentu historycznego, byli nie tylko Francuzi, ale też sami Khmerzy - czy to oficjele Republiki Khmerskiej, czy Czerwoni Khmerzy. Każdy nowy ośrodek władzy obracał się przeciwko staremu. Najczęściej w roli zewnętrznego straszaka powracał w tym scenariuszu Wietnam, a lata 1979-1989 pozostają dla pokolenia dzisiejszych opozycjonistów najświeższym wspomnieniem obcej ingerencji (z wyłączeniem zdecydowanie mniej traumatycznej misji ONZ), bezsprzecznie warunkującym ich myślenie.

Poczucie ciągłego zagrożenia z zewnątrz w połączeniu ze stosowaną przez kolejne rządy retoryką oblężonej twierdzy nie sprzyja akceptacji szeroko rozumianej inności ${ }^{58}$. W paradygmat ten nie wpisują się dziś jedynie nieistotni z punktu widzenia politycznego muzułmańscy Czamowie oraz cieszący się

57 P. Edwards, Imaging the Other..., s. 54.

58 S. Heder, J. Ledgerwood, Politics of violence. An introduction, [w:] Propaganda, politics and violence..., s. 20. 
dużym zaufaniem i szanowani za kulturowy dorobek etniczni Chińczycy ${ }^{59}$. Nie bez znaczenia pozostaje przy tym gospodarcza pomoc Pekinu. Potrzeba stałego dopływu kapitału i nieobwarowanych kłopotliwymi warunkami kontraktów biznesowych sprawia, że władze Kambodży skłonne są nawet ryzykować interesy własnych obywateli, czego najświeższym przykładem jest kampania masowych wywłaszczeń w nadmorskim kurorcie Sihanoukville ${ }^{60}$. Choć ten rodzaj ekspansji jest coraz bardziej powszechny, to model agresywnego uprzemysłowienia wraz z zalewem rynku chińskimi produktami niskiej jakości czy traktowaniem Kambodży jako dostawcy żywności dla południowych prowincji Chin nie został jeszcze, jak się wydaje, wystarczająco skompromitowany, żeby można było $\mathrm{w}$ nim dostrzec bezpośrednie analogie $\mathrm{z}$ dawną dominacją wietnamską.

Drugi czynnik podsycający nacjonalizm wiąże się ze statusem Kambodży, która jest państwem wyłączonym z najważniejszych globalnych procesów politycznych, a w skali regionu z trudem odrabia dystans do pozostałych członków ASEAN. W nietrącącym zbyt wiele na aktualności artykule Lilliputians' dilemmas. Small states in international politics z 1969 r. Robert Keohane nakreślił typografię państw w zależności od ich wpływu na kształtowanie systemu światowego. Na przeciwległych biegunach znalazły się kraje determinujące ów system oraz pozbawione jakichkolwiek środków oddziaływania ${ }^{61}$. Kambodżę zaklasyfikowano w tym ujęciu do najniższej, czwartej kategorii. Jest to państwo zmuszone wchodzić w mnogie porozumienia multilateralne celem zyskania gwarancji bezpieczeństwa czy stabilności ekonomicznej, zależne od międzynarodowych darczyńców i instytucji finansowych oraz szukające akceptacji i partnerstwa u sąsiadów - nawet za cenę drenażu własnych zasobów ludzkich czy materialnych. Perspektywa ta powoduje, że spadkobiercy Imperium Angkor czują się pomijani i upokorzeni, a równocześnie szukają zemsty na sprawcach swojej niedoli.

Opis przypadku dopełnia zawiła sytuacja systemowo-ustrojowa, która nie pozwoliła zmaterializować się w Kambodży jednorodnej wizji państwowości, co utrudniło Khmerom wytworzenie koherentnej osobowości zbiorowej.

59 P. Edwards, Ethnic Chinese in Cambodia. Interdisciplinary research on ethnic groups in Cambodia, final draft, Center for Advanced Study, Phnom Penh 1996, s. 160.

60 K. Kotoski, C. Sokhorng, Big trouble in little China? Exploring Chinese investment in Sihanoukville, „The Phnom Penh Post” [online], 8.12.2017 [dostęp: 25.03.2018], dostępny w internecie: $<$ https://www.phnompenhpost.com/post-depth-business/big-trouble-little-china- $0>$.

61 Zob. R. Keohave, Lilliputians' dilemmas. Small states in international politics, „International Organization" 1969, vol. 23, No. 2. 
Od 1953 r. państwo doświadczyło sześciu różnych reżimów, których wspólnym mianownikiem jest jedynie to, że pogłębiały wrażenie dyskontynuacji wszelkich procesów politycznych. Kolejni przywódcy - Norodom Sihanouk, Lon Nol, Pol Pot i w końcu Hun Sen - skutecznie podważali ducha narodu zaszczepianego i pielęgnowanego wedle określonych kryteriów przez poprzedników. W ten sposób jednym z niewielu elementów pozwalających społeczeństwu identyfikować się poprzez khmerskość pozostała nienawiść do Wietnamu. Jako budulec tożsamości zwykłych ludzi dopełniła ona tradycyjną triadę lokalnego nacjonalizmu, który mniej więcej od lat trzydziestych XX w. bazował na wspólnocie narodu (cheat), religii (sasana) i osoby króla (mohaksatr) ${ }^{62}$.

W kręgu kulturowym Dalekiego Wschodu liderzy polityczni często stanowią jedność z kierowaną przez siebie instytucją, dlatego też państwo posiadało w Kambodży monopol na konsolidowanie społeczeństwa, mając je doprowadzić do jedności i harmonii. Koncepcja ta stała się naczelną ideą cywilnych rządów Norodoma Sihanouka $(1954-1970)^{63}$, którego populistyczne rządy realizowały założenia tzw. buddyjskiego socjalizmu ${ }^{64}$. Bycie Khmerem oznaczało dla niego ciągłą walkę o przetrwanie w niesprzyjającym środowisku międzynarodowym. Opiekuńcza funkcja władcy wymagała od społeczeństwa podporządkowania się odgórnym nakazom i zawierzenia jego dobrym radom, co pociągało za sobą bezwarunkową wierność liderowi, tradycji oraz rasie. Gdy rezultaty danej polityki zaczynały odbiegać od oczekiwań bądź w otoczeniu wodza pojawiali się kontestatorzy aktualnego porządku, najłatwiej było wskazywać jako źródło problemów zewnętrzne siły próbujące zakłócić ład społeczny poprzez szpiegostwo bądź insurekcję. Wykorzystywano wtedy utrwalone schematy i stereotypy z przeszłości ${ }^{65}$. Kolejne reżimy doprowadziły tego rodzaju narracje do perfekcji, czego wyrazem było przekonanie Czerwonych Khmerów, że kołem zamachowym postępu są zjednoczone masy, oraz wywodzące się z tej filozofii postrzeganie Wietnamu jako przeszkody w transformacji ku wyższym formom rozwoju.

62 A. Norén-Nilsson, Cambodia's Second Kingdom, nation, imagination, and democracy, Cornell University, Ithaca 2016, s. 24.

63 Norodom Sihanouk abdykował w 1954 r. na rzecz ojca, króla Norodoma Suramarita, ale w rzeczywistości dalej dysponował największymi uprawnieniami politycznymi jako tytularny premier / przewodniczący państwa z ramienia utworzonej przez siebie na potrzeby elekcji w 1955 r. Ludowej Wspólnoty Socjalistycznej (Sangkum Reastr Niyum).

64 Zob. A. Peang-Meth, Cambodia and the United Nations. Comparative foreign policies under four regimes. Volume I, University of Michigan, Chicago 1980, s. 158-160.

65 B. Kiernan, The Samlaut rebellion and its aftermaths. The origins of Cambodia's liberation movement part II, Monash University, Clayton 1975 (Monash University Working Paper, 5), s. 9. 
Nakreślona powyżej tradycja w swojej pierwotnej formie została w dużej mierze zawłaszczona przez dzisiejszych opozycjonistów. Przez wzgląd na kolaborację z KRDK uważają się oni za kontynuatorów programu Sihanouka i akcentują znaczenie haseł o prawdziwych Khmerach czy khmerskiej ziemi, wieszcząc rychłą apokalipsę, jeżeli kraj nie przeciwstawi się wietnamskiej indoktrynacji uosabianej przez ścisłe kierownictwo KPL. Sam Rainsy zwykł przy tym podkreślać analogię sytuacji na linii Kambodża-Wietnam do losów państwa polskiego, które zniknęło pod okupacją Niemiec i Rosji podczas drugiej wojny światowej ${ }^{66}$. Środowiska bliskie KPON promują narrację, wedle której współczesna Kambodża to w dużej mierze państwo spreparowane, oparte na obcych wzorcach kulturowych i instytucjach kontrolowanych przez nie-Khmerów. Jego nomenklatura ma być uwikłana w dwuznaczne związki z komunistycznym konspiratorem w Hanoi, przez co wciąż oskarżana jest o bycie wietnamską marionetką (ayng yuon) ${ }^{67}$. Równie chwytliwym sloganem podnoszonym podczas wieców czy demonstracji skierowanych przeciwko gabinetowi premiera Hun Sena jest określanie jego członków mianem tych, którzy mają „khmerskie ciała, lecz wietnamskie umysły”. Świadomie lub nie nawiązuje się w ten sposób do retoryki, którą po raz pierwszy wykorzystał Pol Pot, dokładnie takimi słowami zachęcając rodaków w 1978 r. do udziału w antywietnamskich pogromach ${ }^{68}$.

W kontrze do opisanego powyżej stanowiska występuje nieco inne rozumienie nacjonalizmu. Jego wyrazem jest istnienie stabilnych rządów KPL oraz kierowniczej funkcji premiera, który pełni rolę ojca narodu o porównywalnym do dawnych królów statucie i osiągnięciach ${ }^{69}$. Mit stworzony przez współczesnych decydentów Kambodży bazuje na ich heroicznej walce o wyzwolenie kraju spod jarzma Czerwonych Khmerów oraz zaprowadzeniu po 1979 r. upragnionego pokoju, bezpieczeństwa i równowagi. Uznanie po 1993 r. mechanizmów demokratycznych za główne narzędzia wyboru reprezentantów politycznych nie przeszkadza im podkreślać, że głos oddany na opozycję będzie zawsze stracony, a jej ewentualne zwycięstwo to niechybny koniec ery pewności i nowa wojna domowa ${ }^{70}$. W ten sposób KPL pragnie

66 A. Norén-Nilsson, Cambodia's..., s. 131.

67 C. Hughes, Transforming oppositions in Cambodia, „Global Society” 2001, vol. 15, No. 3, s. 19.

68 A. Mertha, Brothers in arms. Chinese aid to the Khmer rouge, 1975-1979, Cornell University Press, New York 2014, s. 96.

69 A. Norén-Nilsson, Cambodia's..., s. 39.

70 K. Karim, Hun Sen talk of war dismissed by CNRP, „Khmer Times” [online], 15.05.2017 [dostęp: 25.03.2018], dostępny w internecie: <https://www.khmertimeskh.com/news/ 38346/hun-sen-talk-of-war-dismissed-by-cnrp/>. 
odwrócić uwagę od swojej wietnamskiej przeszłości i udowodnić, że wobec dokonań ugrupowania jego rodowód nie jest istotny. Tak skonstruowane rozumienie nacjonalizmu wpisuje się w szerszą koncepcję rządów opartą o doktrynę tzw. demokracji ludowej (people’s democracy) ${ }^{71}$. Jej pomysłodawcą jest Hun Sen, który buduje autorski program polityczny w przekonaniu, że wszelką pomyślność i rozwój gwarantuje brak zmian na szczytach władzy. Za jego wizją wciąż opowiada się około połowy aktywnych wyborców - ludzie zależni od patronacko-klientelistycznych stosunków w ramach rozbudowanej sieci administracji, urzędnicy, grupy uprzywilejowanych przedsiębiorców korzystających z utrzymującej się koniunktury gospodarczej, a najpewniej także ci, którzy po prostu ufają szefowi państwa.

\section{Podsumowanie}

Na kambodżańskiej scenie politycznej nie wykształciło się racjonalne i wiarygodne centrum, które wykorzystywałoby nacjonalizm do promowania pozytywnych wartości afirmujących khmerskość. Okazało się to zabójcze zarówno dla KPON, jak i kambodżańskiej demokracji. Emocje, które od kilkunastu lat towarzyszą sporom na temat znaczenia Wietnamu w polityce wewnętrznej Kambodży, a także stojące za nimi interesy określonych grup wytworzyły sytuację patową, a delegalizacja największej partii opozycyjnej jest tylko spodziewaną konsekwencją wzrostu popularności tego ugrupowania i jego interpretacji historii. Z perspektywy KPL nasilający się rasizm i ksenofobia wobec Wietnamczyków kryły drugie dno - dezaprobatę dla elit, czyli de facto podważały legitymizację systemu. W khmerskim środowisku politycznym - tradycyjnie skłonnym do populizmu i odwoływania się do przerysowanych symboli narodowych jako skuteczniejszych środków mobilizacji elektoratu niż realne propozycje polityczneperspektywa wzmocnienia narracji opozycji była więc nie do przyjęcia.

W świetle przytoczonych faktów nie powinno dziwić, że nastawiona antywietnamsko KPON - uznawana za formację pozbawioną realnego programu naprawy państwa, cierpiąca na niedobór technokratów zdolnych do materializacji obiecanych reform i uprawiająca politykę w oparciu o charyzmę wąskiej grupy przywódców - już w 2013 r. była o krok od objęcia rządów w Kambodży, bazując w dużej mierze na społecznych lękach przed sąsiadem ${ }^{72}$.

71 Zob. A. Norén-Nilsson, Cambodia 's..., s. 120-129.

72 D. Hutt, Sam Rainsy's last stand?, „Southeast Asia Globe” [online], 16.12.2016 [dostęp: 25.03.2018], dostępny w internecie: <http://sea-globe.com/sam-rainsy/>. 
Obawa przed ponowną kolonizacją to coś więcej niż demagogia polityków. Postulowana redefinicja stosunków pomiędzy LRK i Wietnamem w duchu parakolonializmu nie zmieni zbiorowej świadomości oraz wielopokoleniowych przekonań, niemniej przez wzgląd na dezintegrację obozu opozycji należy się spodziewać okresowego złagodzenia dyskursu opartego o antywietnamskie resentymenty. Przebywający na banicji we Francji Sam Rainsy i osadzony w więzieniu w związku z zarzutami o próbę zamachu stanu Kem Sokha muszą najpierw zastanowić się, w jakim kształcie odbudować rozbite struktury partyjne i czy dalej polegać na sobie jako partnerach koalicyjnych. Wietnam zapewne zejdzie na dalszy plan politycznej agendy, ustępując miejsca dyskusji i walce o istotę demokracji w Kambodży.

Ewentualna eskalacja napięć byłaby wyobrażalna jedynie w następstwie niespotykanej radykalizacji tych zwolenników KPON, którzy uznają, że jak nigdy przedtem aktualne stają się słowa Sam Rainsy'ego z 2013 r., kiedy to przepowiedział nadejście nowej ery wietnamskiej niewoli, będącej rezultatem braku przetasowań na khmerskiej scenie politycznej do czasu wyborów w $2018 \mathrm{r}^{73} \mathrm{Na}$ razie trudno jednak uwierzyć w taki scenariusz, skoro nawet jawnie ukartowane rozbicie KPON nie przekonało ludzi do wyjścia na ulice. Nie powtórzyła się tym razem sytuacja sprzed pięciu lat, gdy rzekome fałszerstwa wyborcze doprowadziły do wielomiesięcznych protestów i strajków sympatyków opozycji. Upadek KPON to raczej szansa na wzmocnienie i dalszy niezakłócony rozwój oficjalnych stosunków państwowych. Brak presji politycznej umożliwi KPL skoncentrowanie się na takich zagadnieniach jak regionalna współpraca gospodarcza czy bezpieczeństwo, a etniczni Wietnamczycy przestaną być elementem rozgrywek politycznych. Pierwszym dowodem uelastycznienia stanowiska władz w tej kwestii są wstępne ustalenia poczynione w styczniu 2018 r., podczas rozmów premierów Kambodży i Wietnamu w ramach szczytu inicjatywy Lancang-Mekong. Hun Sen zapewnił wówczas, że w najbliższych miesiącach dojdzie do przyjęcia regulacji legalizujących pobyt dużej grupy Wietnamczyków w Kambodży, co wiąże się z dyskutowaną od późnych lat dziewięćdziesiątych kwestią otrzymania przez nich podwójnego obywatelstwa ${ }^{74}$.

73 C. Osterheld, , Scapegoating Cambodia's “youn”..., s. 579.

74 K. Meta, A. Nachemson, Vietnamese government, Hun Sen seek solution on legal status, „The Phnom Penh Post” [online], 11.01.2018 [dostęp: 25.03.2018], dostępny w internecie: <https://www.phnompenhpost.com/national/vietnamese-government-hun-sen-seek-solution-legal-status>. 
Parakolonializm wietnamski jako czynnik kształtujący współczesny dyskurs o polityce...

\section{Bibliografia}

Amer R., Border Conflicts between Cambodia nad Vietnam, „IBRU Boundary and Security Bulletin" 1997, Summer.

Ashcroft B., Grittiths G., Tiffin H., Post-colonial studies. The key concept, Routledge, New York 2000.

Babović M., Vuković D., Cambodia. A survey of livelihood strategies and expectations for the future, The Asia Foundation 2015, dostępny w internecie [dostęp: 16.02.2018]: <https://asiafoundation.org/resources/pdfs/CambodiaLivelihoodsandFutureExpecationsSurvey.pdf $>$.

Building GMS, CLV regions of sustainable, prosperous development, „Vietnam Economic News" [online], 2.04.2018 [dostęp: 2.04.2018], dostępny w internecie: <http://ven.vn/ building-gms-clv-regions-of-sustainable-prosperous-development-31801.html>.

Cambodia - ethnic minorities, „Minority Rights Group International” [online], listopad 2017 [dostęp: 25.03.2018], dostępny w internecie: <http://minorityrights.org/minorities/ ethnic-vietnamese/>.

Cambodia. Progress and change since 1991, ed. P. Sothirak, G. Wade, M. Hong, Institute of Southeast Asian Studies, Singapore 2012.

Chanda N., Blood brothers, „Far Eastern Economic Review”, 3.12.1992.

Chheang V., Cambodia-Vietnam ties turn 50, „East Asia Forum” [online], 21.06.2017 [dostęp: 25.03.2018], dostępny w internecie: <http://www.eastasiaforum.org/2017/06/21/ cambodia-vietnam-ties-turn-50/>.

Chronology of hate crimes against Vietnamese in Cambodia (part 2), „Khmer Times” [online], 15.04.2014 [dostęp: 25.03.2018], dostępny w internecie: <https://www.khmertimeskh.com/ news/870/chronology-of-hate-crimes-------against-vietnamese-in-cambodia--part-2-/>.

Dara M., Sokhean B., Hun Sen tells jailed opposition figures not to expect pardon, „The Nation” [online], 7.03.2018 [dostęp: 25.03.2018], dostępny w internecie: <http://www.nationmultimedia.com/detail/asean-plus/30340397>.

Democracy in Cambodia - 2003. A survey of the Cambodian electorate, ed. T. Meisburger, The Asia Foundation 2003, dostępny w internecie [dostęp: 16.02.2018]: <https://asiafoundation.org/resources/pdfs/DemocracyinCambodia.pdf $>$.

Democracy in Cambodia - 2014. A survey of the Cambodian electorate, The Asia Foundation 2014, dostępny w internecie [dostęp: 16.02.2017]: <https://asiafoundation.org/resources/ pdfs/DemocracyinCambodia2014.pdf>.

Edwards P., Ethnic Chinese in Cambodia. Interdisciplinary research on ethnic groups in Cambodia, final draft, Center for Advanced Study, Phnom Penh 1996.

Edwards P., Imaging the Other in Cambodian nationalist discourse before and during the UNTAC period, [w:] Propaganda, politics, and violence in Cambodia. Democratic transition under United Nations peace-keeping, ed. S. Heder, J. Ladgerwood, East Gate Books, New York 1996.

Ehrentraut S., Challenging Khmer citizenship. Minorities, the state, and the international community in Cambodia, rozprawa doktorska, Uniwersytet Poczdamski, 2013.

Fawthrop T., In Cambodia racist rhetoric brings death threats to human rights activist, „East by Southeast” [online], 22.01.2014 [dostęp: 25.03.2018], dostępny w internecie: <http://www.eastbysoutheast.com/in-cambodia-racist-rhetoric-brings-death-threats-to-human-rights-activists/>. 
Frewer T., Cambodia's anti-Vietnam obsession, „The Diplomat” [online], 6.09.2016 [dostęp: 25.03.2018], dostępny w internecie: <https://thediplomat.com/2016/09/cambodias-anti-vietnam-obsession/>.

Guan A.C., Vietnam-Cambodia relations from the Paris Peace Conference (1991) to membership of ASEAN, „South East Asia Research” 2000, vol. 8, No. 1.

Head J., Vietnam firms involved in 'illegal land grabs', „BBC” [online], 13.05.2013 [dostęp: 25.03.2018], dostępny w internecie: <http:/www.bbc.com/news/world-asia-22509425>.

Heder S., Ledgerwood J., Politics of violence. An introduction, [w:] Propaganda, politics, and violence in Cambodia. Democratic transition under United Nations peace-keeping, ed. S. Heder, J. Ladgerwood, East Gate Books, New York 1996.

Horvath R.J., A definition of colonialism, „Current Anthropology” 1972, vol. 13, No. 1.

Hughes C., Khmer land, Khmer soul. Sam Rainsy, populism, and the problem of seeing Cambodia, „South East Asia Research” 2001, vol. 9, No. 1.

Hughes C., Transforming oppositions in Cambodia, „Global Society” 2001, vol. 15, No. 3.

Hunt L., Why is Cambodia's illegal logging problem still rolling on?, „The Diplomat” [online], 10.05.2017 [dostęp: 25.03.2018], dostępny w internecie: <https://thediplomat. com/2017/05/why-is-cambodias-illegal-logging-problem-still-rolling-on/>.

Hutt D., Sam Rainsy. A coward?, „The Diplomat” [online], 23.06.2016 [dostęp: 25.03.2018], dostępny w internecie: $<$ https://thediplomat.com/2016/06/sam-rainsy-the-coward/>.

Hutt D., Sam Rainsy's last stand?, „Southeast Asia Globe” [online], 16.12.2016 [dostęp: 25.03.2018], dostępny w internecie: <http://sea-globe.com/sam-rainsy/>.

Hutt D., The truth about anti-Vietnam sentiment in Cambodia, „The Diplomat” [online], 20.10.2016 [dostęp: 25.03.2018], dostępny w internecie: <https://thediplomat. com/2016/10/the-truth-about-anti-vietnam-sentiment-in-cambodia/>.

Karim K., Hun Sen talk of war dismissed by CNRP, „Khmer Times” [online], 15.05.2017 [dostęp: 25.03.2018], dostępny w internecie: <https:/www.khmertimeskh.com/news/38346/ hun-sen-talk-of-war-dismissed-by-cnrp/>.

Keohave R., Lilliputians' dilemmas. Small states in international politics, „International Organization" 1969, vol. 23, No. 2.

Khmer Krom. Khmer Kampuchea-Krom Federation (KKF). Member Profile, Unrepresented Nations and Peoples Organization, Washington 2018, dostępny także w internecie [dostęp: 25.03.2018]: <https://unpo.org/members/7887>.

Kiernan B., The Samlaut rebellion and its aftermaths. The origins of Cambodia's liberation movement part II, Monash University, Clayton 1975 (Monash University Working Paper, 5).

Kimseng M., Not only Vietnamese threatened by racism, human rights worker says, „VOA Cambodia" [online], 25.02.2014 [dostęp: 25.03.2018], dostępny w internecie: <https:// www.voacambodia.com/a/not-only-vietnamese-threatened-by-racism-rights-workersays/1858791.html>.

Kotoski K., Sokhorng C., Big trouble in little China? Exploring Chinese investment in Sihanoukville, „The Phnom Penh Post” [online], 8.12.2017 [dostęp: 25.03.2018], dostępny w internecie: $<$ https://www.phnompenhpost.com/post-depth-business/big-trouble-little-china-0>.

Kunthear M., Clash at Vietnam embassy, „The Phnom Penh Post” [online], 9.06.2014 [dostęp: 25.03.2018], dostępny w internecie: <https://www.phnompenhpost.com/national/ clash-vietnam-embassy>.

Leng T., 2016: a promising year for Cambodia?, „Southeast Asian Affairs” 2017, vol. 1. 
Parakolonializm wietnamski jako czynnik kształtujący współczesny dyskurs o polityce...

Leng T., Small state diplomacy. Cambodia's foreign policy towards Vietnam, „The Pacific Review" 2017, vol. 30, No. 3.

Loomba A., Colonialism/postcolonialism, Routledge, New York 2005.

Mertha A., Brothers in arms. Chinese aid to the Khmer rouge, 1975-1979, Cornell University Press, New York 2014.

Meta K., Nachemson A., Vietnamese government, Hun Sen seek solution on legal status, „The Phnom Penh Post” [online], 11.01.2018 [dostęp: 25.03.2018], dostępny w internecie: <https://www.phnompenhpost.com/national/vietnamese-government-hun-sen-seek-solution-legal-status $>$.

Millar P., Race to the bottom. How Cambodia's opposition is targeting ethnic Vietnamese, „Southeast Asia Globe” [online], 21.10.2016 [dostęp: 25.03.2018], dostępny w internecie: <http://sea-globe.com/cambodia-opposition-cnrp-vietnamese/>.

Norén-Nilsson A., Cambodia's Second Kingdom, nation, imagination, and democracy, Cornell University, Ithaca 2016.

Opposition leader Kem Sokha talks politcs, power and Hun Sen, „You Tube” [online], 20.06.20147 [dostęp: 25.03.2018], dostępny w internecie: <https://www.youtube.com/ watch?time_continue $=201 \& \mathrm{v}=$ Slu3YOP-K_8>.

Osterheld C., Scapegoating Cambodia's “yuon”. Historical perspectives on Khmer anty-Vietnamism, [w:] Proceedings of the $10^{\text {th }}$ International Academic Conference, Vienna, Austria, 03-06 June 2014, ed. J. Rotschedl, K. Čermáková, Prague 2014.

Pann M., Anti-Vietnam fears stoked ahead of Cambodia election, „VOA News” [online], 20.04.2017 [dostęp: 25.03.2018], dostępny w internecie: <https://www.voanews.com/a/ cambodian-opposition-expected-to-play-anti-vietnamese-sentiment-ahead-of-elections/ 3818107.html>.

Peang-Meth A., Cambodia and the United Nations. Comparative foreign policies under four regimes. Volume I, University of Michigan, Chicago 1980.

Proceedings of the $10^{\text {th }}$ International Academic Conference, Vienna, Austria, 03-06 June 2014, ed. J. Rotschedl, K. Čermáková, Prague 2014.

Propaganda, politics, and violence in Cambodia. Democratic transition under United Nations peace-keeping, ed. S. Heder, J. Ladgerwood, East Gate Books, New York 1996.

Rainsy S., Letter to the editor: 'Yuon' may be incorrect, but not offensive, „The Cambodia Daily” [online], 10.07.2017 [dostęp: 25.03.2018], dostępny w internecie: <https://www.cambodiadaily.com/news/letter-editor-yuon-may-incorrect-not-offensive-132327/>.

Seabrook J., The metamorphoses of colonialism, „Globalization” 2001, vo1. 1, dostępny w internecie [dostęp: 25.03.2018]: <http://globalization.icaap.org/content/v1.1/jeremyseabrook.html>.

Soja P., Polityka zagraniczna Demokratycznej Kampuczy w latach 1975-1979, „Przegląd Geopolityczny" 2017, nr 20.

Sovuthy K., CNRP president Sam Rainsy sentenced to a further five years in prison, „The Cambodia Daily" [online], 27.12.2016 [dostęp: 25.03.2018], dostępny w internecie: $<$ https://www. cambodiadaily.com/news/cnrp-president-sam-rainsy-sentenced-five-years-prison-122517/>.

Springer S., Cambodia's neoliberal order. Violence, authoritarianism, and the contestation of public space, Routledge, New York 2010.

Strangio S., Hun Sen's Cambodia, Yale University Press, New Haven 2014.

Survey of Cambodian public opinion, International Republican Institute 2013, dostępny w internecie [dostęp: 16.02.2017]: <http://www.iri.org/sites/default/files/Cambodian\%20Poll\%20 9\%20Final\%20PUBLIC.pdf $>$. 
Thayer C.A., Cambodia and Vietnam. Good fences make good neighbours, [w:] Cambodia. Progress and change since 1991, ed. P. Sothirak, G. Wade, M. Hong, Institute of Southeast Asian Studies, Singapore 2012.

Trang T., Vietnam, Cambodia intensify defense cooperation, „People's Army Newspaper” [online], 18.01.2018 [dostęp: 25.03.2018], dostępny w internecie: $<$ http://en.qdnd.vn/military/ intl-relations-and-cooperation/vietnam-cambodia-intensify-defense-cooperation-489023>.

Vida T., CNRP: Vietnamese renting land, „Khmer Times” [online], 26.10.2016 [dostęp: 25.03.2018], dostępny w internecie: <https://www.khmertimeskh.com/news/28992/ cnrp--vietnamese-renting-land>.

Vietnamese derogatory word yuon, hate crimes and CNRP, „Khmer Times” [online], 14.04.2014 [dostęp: 25.03.2018], dostępny w internecie: $<$ https://www.khmertimeskh.com/news/849/ vietnamese-derogatory-word------quot-yuon--quot--hate-crimes-and-cnrp/>.

Vietnam's imports of Cambodian logs and sawnwood from natural forests: 2013-2015, „,Forest Trends Report Series", listopad 2016, dostępny w internecie [dostęp: 20.07.2018]: <https:// www.forest-trends.org/wp-content/uploads/imported/vietnam-cambodia-report-formatted final_11-23-16-pdf.pdf>.

Vizenor G., Manifest manners. Narratives on postindian survinance, University of Nebraska Press, Lincoln 1999.

Willemys A., CNRP clings to anti-Vietnamese rhetoric, „The Phnom Penh Post” [online], 26.06.2017 [dostęp: 25.03.2018], dostępny w internecie: $<$ https://www.phnompenhpost. com/national/cnrp-clings-anti-vietnamese-rhetoric $>$. 